\title{
The Essential, Objective and Functional Characteristics of the Students' Academic Mobility in Higher Education
}

\author{
Regina G. Sakhieva ${ }^{1}$, Rinat R. Ibatullin ${ }^{2}$, Milyausha K. Biktemirova ${ }^{2}$, Gyuzel K. Valeyeva ${ }^{3}$, Olga V. Pchelina ${ }^{4}$, \\ Nailya S. Valeyeva ${ }^{5}$, Venera N. Minsabirova ${ }^{2} \&$ Elmira R. Khairullina ${ }^{5}$ \\ ${ }^{1}$ Academy of Social Education, Kazan, Russia \\ ${ }^{2}$ Kazan (Volga region) Federal University, Kazan, Russia \\ ${ }^{3}$ Sibay institute (branch) of Bashkir State University, Sibay, Russia \\ ${ }^{4}$ Volga State University of Technology, Yoshkar-Ola, Russia \\ ${ }^{5}$ Kazan National Research Technological University, Kazan, Russia \\ Correspondence: Regina G. Sakhieva, Academy of Social Education, Isaeva Street 12, Kazan, 420039, Russia. \\ E-mail: saxievarg@mail.ru
}

Received: January 17, 2015

Accepted: January 29, 2015 Online Published: February 26, 2015

doi:10.5539/res.v7n3p335

URL: http://dx.doi.org/10.5539/res.v7n3p335

\begin{abstract}
The globalization of education triggers fair criticism of the university self-sufficiency in any country to train competent professionals, moreover, today the necessity to expand the students' academic mobility is universally recognized. The article describes the basic methodological approaches to defining the essence of the concept of "academic mobility". It explores the goal, objectives, functions of the students' academic mobility in the context of international educational integration. This publication submits a classification of the forms of academic mobility of the higher education students on the following grounds: on the type of educational process, on the period of study in a foreign educational establishment, on the nature of the students' involvement. The article can be useful to the academic staff of higher educational institutions, to the staff of the university centers of academic mobility as well as the employees of the university international departments in the development of international cooperation and academic mobility of the students.
\end{abstract}

Keywords: mobility, academic mobility, international educational integration, common education space

\section{Introduction}

The end of the 20th - the beginning of the 21st century is the period of global innovation in economy, technology, culture, science and education accompanied by accelerated development of all aspects of social life. As a reaction to the dynamism of changes in modern society the growing role of the individual in all running processes has formed a new paradigm of education which has been called "learning through life." It is intended to include everyone in the continuous process of acquiring knowledge, values, attitudes, general cultural and professional competences. The modern development of the society has resulted in a rapidly evolving process of globalization. The science introduced such concepts as "international educational integration", "academic mobility", "common education space." Education in the age of globalization calls to provide everyone with an opportunity to make a choice involving a combination of specific professional knowledge and skills with the needs of the individual development, formation of civil qualities and moral attitudes (Merzon et al., 2015; Sakhieva et al., 2015; Khanmurzina et al., 2015). There are various and opposing views on the ongoing process of globalization, but the process is never-ending as it is objectively natural. In the process of globalization the education is entering a new phase of international educational integration.

The international educational integration (at the supranational level) we define as an objective process of sustainable interaction and mutual influence of the national educational systems based on common objectives and principles meeting the needs of international community and reflecting the progressive trends of the new century. The international educational integration (at the institutional level) we define as the process of expanding the scope of the institution activities beyond its educational system, the development of international education relations and coordination of the institution activities with the internationally recognized standards (Ivanov et al., 2015; Shaidullina et al., 2015; Fayzullina \& Mukhametzyanova-Duggal, 2015). 
Now we can observe the moment of historic development when the national isolation of the universities is colliding with the effects and prospects of globalization. In the course of education globalization the academic mobility is one of the conditions for the development and self-actualization of the person in the world.

\section{Literature Review}

The idea of academic mobility in the context of globalization, integration, internationalization of higher education is reflected in the works of Baydenko (2010), Galichina, Karpukhina and Matveeva (2009), Bogoslovskiy, Pisareva and Tryapitsina (2007), Kuzmin (2007), Oleinikova (2009), Chistokhvalova and Filippova (2008).

Particularly the formation and development of academic mobility of the students in Russia and abroad is discussed in the research of Znovenko (2008), Tregubova, Sakhieva and Masalimova (2008), Sheremet (2009).

Academic mobility has been studied by many foreign scientists: Apple (2005), Buhm and Meares (2003), Byram and Dervin (2008), Cummings (2006), Loveland (2008), Papatsiba (2006), Rivza and Teichler (2007), Sylvia (2000).

The study of scientific literature has allowed to conclude that a person is mobile if he has adapted to the new modern formation, is capable of improving, responding malleably to the new requirements and conditions of existence and is adapting to them. The explanatory psychological dictionary refers mobility to the concept of "movement" that can be understood literally as a physical movement of a stimulus, object or organism or metaphorically as a movement through the areas that may be social, professional or cognitive (Reber, 2001). The classic sense of the term is the mobility of an individual, the ability for rapid action, the readiness to anything.

At present an unambiguous and authorized definition of the term "academic mobility" does not exist.

In the documents of the Council of Europe, namely in the recommendations of the Committee of Ministers of the Council of Europe, 1996, academic mobility is defined as a period of learning, teaching and / or research in a country other than the country of residence of a student or academic staff member and emphasizes that this period should have a limited duration, thus providing that a student or an employee returns to his or her home country upon completing the specified period (The Documents of International Law on Education, 2003).

Often the term "academic mobility" supposes not only the movement of the students and academic staff to overseas educational institutions in a relatively short period of time for studying, research or internship with mandatory return to their home institution as it is stipulated in the international instruments but also the movement of educational technologies, teaching materials and even a technological product created in an education institution (the Appendix of the international aspects of higher education, 2000).

Andris Barblan interprets academic mobility as equal opportunities for accessing multiple providers and service users in the field of higher education, equal support in knowledge development, equal assessment conditions, appreciation of the services, skills and abilities (Barblan, 2002).

V. I. Bogoslovskiy, S. A. Pisareva, A. P. Tryapitsina determine academic mobility as an opportunity for the students (primarily), teachers, administrative university staff to move from one institution to another in order to share experiences, get the opportunities that are not available for some reason in their university, overcome national isolation and acquire pan-European prospects (Bogoslovskiy, Pisareva, \& Tryapitsina, 2007).

According to N. S. Brineva, academic mobility is an essential form of existence of the intellectual potential and an opportunity to shape an educational trajectory and to choose the subjects, courses, education institutions within the education standards and in accordance with one's own inclinations and aspirations (Brin \& Chuyanov, 2001).

\section{Methodological Framework}

The most methodologically reasonable while considering the concept of "mobility" in general seems the systematic, evolutionary and anthropological approaches. Considering the concept of "academic mobility" along with the abovementioned approaches we also consider the socio-cultural, humanistic and person-activity approaches. All these approaches are intended to enhance, implement and develop human potential, where the criteria include the personal completeness, the level of activity including a cognitive one, freedom of behavior and activities of the individual in a cultural space who is developing as a social (identity) and individual (individuality) creature.

In modern methodology the most complete understanding of the integrative qualities of the personality is represented by the system approach. From this perspective the academic mobility can be viewed as a system consisting of such characteristics as: personal activity, academic and intercultural competence which is based on 
readiness for educational and self-educational activity in the process of establishing the common education space, flexibility, basing on adaptability as a personal property, independence, critical thinking, creativity, reflection.

The main aspect of the evolutionary approach influencing the notions of academic mobility and determination of its essence is the following: if the process of development is analyzed in terms of continuity and interdependence then the person's mobility becomes an immediate condition of this process since it allows him to move, to evolve, to change. However, it is not particularly the development process that appeals but the quality of its course; only in this aspect the academic mobility can be regarded as a condition that determines the quality of education and self-education activity.

The anthropological approach focuses on a holistic and systemic vision of a man as a way of integrating different knowledge about it in terms of formation and development. This approach also contributes to the emergence of prerequisites for the development of the appropriate educational strategies in the process of academic mobility, based on full consideration of the laws of personal development. In the process of academic mobility development the formation of a free and responsible person capable of providing education and self-education activity in today's multicultural world, combining academic and intercultural competence with civil liability, having philosophical outlook and moral consciousness is of the utmost importance.

In the context of formation of the common education space in order to explore the concept and definition of academic mobility the socio-cultural approach is the most appropriate. The approach promotes shifting the focus of research from the pedagogical phenomena to the person as a subject and a culture bearer, who for the purposes of academic mobility appears as a molding personality under formation, the aspirations vector of whom is driven by the social ideal. From the perspective of this approach the pedagogic concepts and educational practices should form an ethical ideal embodying the components of a particular culture. In this case, the education system in the context of academic mobility becomes a condition for providing the dynamics of the student's personal formation and development towards the ideal.

The initial understanding of the concept of " the students' academic mobility " in the context of humanistic and personal-activity approaches involves turning of the educational activities to the student's personality, creating conditions for his personality approvement and development, maximum satisfaction of his needs, interests and personal characteristics in the learning process. In this case the student acts as a full member, the subject of the educational process based on the principles of partnership and conscious interaction with the teacher, which is directly related to the development of the student's autonomy, his creativity and personal responsibility for the effectiveness of educational and self-educational activity.

\section{Results and Discussions}

Academic mobility of a student determines the nature of his educational and self-educational activity and manifests itself in the ability to plan and implement not only the nearest, but also long-term educational goals, respond quickly to the changes in the educational environment, be able to quickly mobilize forces to accelerate achieving the educational goals, to self-project, self-educate, self-develop causing a change in the traditional requirements to the individual student's ability to effectively communicate interpersonally and interculturally, adhere to universal values and ethical ideals.

The main purpose of academic mobility of the students is to ensure the education quality, to provide his conformity to modern requirements to the personality, the society and the state in the face of international educationintegration.

The main objectives of academic mobility of the students are:

1) To provide the students with an opportunity to test themselves in a different system of higher education and to enhance prestige of the education they receive;

2) To develop the students' new skills and competencies;

3) To expand social and cultural horizons of the students, improve foreign language proficiency and intercultural communication skills;

4) To increase the availability of education at all levels throughout life.

The functions of academic mobility of the university students in the international education and labor market can be divided into four groups based on the following grounds:

Group 1: supranational functions, i.e. the functions of academic mobility at the level of interaction and mutual enrichment of the different national educational systems, supranational worldwide relations and international cooperation that are conditioned by international policy in the field of education, namely: 
- The development of integration processes in higher education;

- The international market development and support in educating competent professionals, the development of supranational structures of the education supply and quality control;

- The improvement of the university graduates employment efficiency.

Group 2: national functions, i.e. the functions of academic mobility at the level of the certain select national educational systems and states, namely:

- Improving the quality of education and research through the students' and teachers' participation in the international process of knowledge and experience exchange;

- Increasing the country competitiveness in the field of education services;

- Increasing the financial revenue by attracting foreign students on a fee-paying basis.

Group 3: the institutional functions, i.e. the functions of academic mobility at the level of specific educational institutions, namely:

- Increasing the prestige and status of a particular educational institution in the international arena;

- Expanding international cooperation between the institutions of higher education;

- Developing the information and education environment of the institution, which allows it to radically upgrade the technological basis, pass to the new information-pedagogic technologies that conform to the system of open education;

- Including in the curricula the disciplines and courses that reveal the integration aspects of modern education ("Culture and intercultural interaction in today's world", "Multicultural education", "International educational integration", etc.) and the principle of tolerance.

Group 4: personalized functions, i.e. the functions of academic mobility at the level of an individual personality, namely:

- Formation of the individual education trajectory of personal development;

- The creation of new knowledge, general cultural and professional competence;

- Improving the foreign languages fluency, intercultural communication skills;

- Review of the foreign culture, history, etc.

Based on the analysis of the national and foreign papers on academic mobility of the students in higher education (Bogoslovskiy, Pisareva \& Tryapitsyna, 2007; Buhm \& Meares, 2003; Byram \& Dervin, 2008; Galichin, Karpukhina \& Matveev, 2009; Loveland, 2008; Znovenko, 2008, etc.) we can identify and characterize the basic forms of academic mobility on the following grounds.

- The type of the education process organization:

1) True academic mobility implemented in two forms:

a) Organized mobility that is carried out and regulated by the relevant programs, academic exchange agreements between the governments, higher education institutions or associations;

b) "Spontaneous" mobility that is implemented beyond the schemes and programs as it is initiated by individual students;

2) Virtual academic mobility that is carried out through the latest technical equipment, and supposes the transition from the limited conception of the student' physical movement from one country to another to the concept of mobile ideas, knowledge and education;

3) Mixed academic mobility, which includes both real and virtual academic mobility;

- According to the period of study at a foreign institution:

1) Vertical academic mobility, that means receiving higher education and a relevant degree and a document;

2) Horizontal academic mobility, that implies a short-term training (during a semester or an academic year) abroad without getting a document of higher education;

- According to the nature of the students' involvement:

1) International, subdivided in turn into intercontinental and inter-country academic mobility (in the first case the academic mobility involves the students from different continents, in the second -from different countries); 
2) Transnational academic mobility, with not a student but an education service crossing the border. This process is organized in the following ways:

a) The student being on the territory of the state is educated in a foreign university using modern means of communication;

b) A foreign university establishes a subsidiary or a branch in the territory of another country for the purpose of providing educational services to the students (in the first case we are talking about distance learning, the second case is a form of foreign investment the result of which is creating a branch of the university);

3) Inter-regional academic mobility that is carried out between the country regions;

4) Inter-university academic mobility which is organized under the agreements between universities.

\section{Conclusion}

Therefore, academic mobility is one of the important conditions for the person's development and self-actualization in terms of international integration. It gives the students the opportunity: to continue their education at a foreign institution of higher education; to independently shape the educational trajectory in accordance with the interests, aptitudes, needs ; to gain additional knowledge in the related fields; to improve foreign language skills, intercultural communication; familiarize yourself with the foreign culture, history, etc.

\section{Reference}

Apple, M. W. (2005). Globalizing Education: Policies, Pedagogies and Politics (p. 311). New York: Peter Lang.

Barblan, A. (2002). Academic cooperation and freedom of movement in Europe: What was and what will be. Higher Education in Europe, 1, 13-16.

Baydenko, V. I. (2010). The main trends in higher education: Global and Bologna measurement (p. 352). Moscow: Research Center of Problems the quality of specialists training.

Bogoslovsky, V. I., Pisarev, S. A., \& Tryapitsina, A. P. (2007). Academic mobility: The implementation of the Bologna Process (p. 55). St. Petersburg: Russian State Pedagogical University.

Brinev, N. S., \& Chuyanov, R. A. (2001). Academic mobility of students as a factor in the development of education. International scientific-practical conference correspondence (pp. 31-34). Omsk: Omsk State Pedagogical University.

Buhm, A., \& Meares, D. (2003). Global Student Mobility 2025: Analysis of Future Labour Market Trends and the Demand for International Higher Education (p. 172). Australia: IDP.

Byram, M., \& Dervin, F. (2008). Students, Staff and Academic Mobility in Higher Education (p. 320). Cambridge: Cambridge Scholars Publishing.

Chistokhvalov, V. N., \& Filipov, V. M. (2008). Status, trends and problem of academic mobility in the European Higher Education Area (p. 162). Moscow: Peoples' Friendship University of Russia.

Cummings, W. K. (2006). Where are international students going? International Higher Education, 43, 5-17.

Fayzullina, A. R., \& Mukhametzyanova-Duggal, R. M. (2015). Multi-Confessional Societies in Russia and India: Models of Relations between the State and Religious Associations. Review of European Studies, 7(1), 12-17.

Galichin, V. A., Karpukhina, E. A., \& Matveev, V. V. (2009). Academic mobility in the internationalization of education (p. 460). Moscow: Universitetskaya Kniga.

Ivanov, V. G., Shaidullina, A. R., Drovnikov, A. S., Yakovlev, S. A., \& Masalimova, A. R. (2015). Regional Experience of Students' Innovative and Entrepreneurial Competence Forming. Asian Social Science, 11(1), 35-40.

Khanmurzina, R. R., Sinitzyn, O. V., Kaviyev, A. F., Burdukovskaya, E. A., \& Lebedeva, I. V. (2015). Practical Recommendations for Optimizing the Process of Formation and Development of Academic Mobility of Students in Higher Educational Institutions of Russia. Review of European Studies, 7(1), 41-45.

Kuzmin, A. V. (2007). Academic mobility management as a factor in the development of international integration in education (p. 26) (Author's abstract of dissertations of candidate of economic sciences). St. Petersburg: Russian State Pedagogical University.

Loveland, E. (2008). Student Mobility in the European Union. International Educator, 17(6), 22-25.

Merzon, E. E., Fayzullina, A. R., Ibatullin, R. R., Krylov, D. A., Schepkina, N. K., Pavlushkina, T. V., \& 
Khairullina, E. R. (2015). Organizational and Pedagogical Conditions of Academic Mobility Development of Students at School of Higher Professional Education. Review of European Studies, 7(1), 46-51.

Oleinikova, O. N. (2009). The Bologna process and the comparability of programs, diplomas and higher education qualifications. In Bulletin of the Moscow State Open University (pp. 13-25). Moscow: Moscow State Open University.

Papatsiba, V. (2006). Making higher education more European through student mobility, Revisiting EU initiatives in the context of the Bologna process. Comparative Education, 42(1), 93-111. http://dx.doi.org/10.1080/03050060500515785

Reber, A. (2001). The Big Explanatory Psychological Dictionary (Vol 1, p. 327) (Trans. from English). Moscow.

Rivza, B., \& Teichler, U. (2007). The Changing Role of Student Mobility. Higher Education Policy, 20(4), 457-475. http://dx.doi.org/10.1057/palgrave.hep.8300163

Sakhieva, R. G., Khairullina, E. R., Khisamiyeva, L. G., Valeyeva, N. S., Masalimova, A. R., \& Zakirova, V. G. (2015). Designing a Structure of the Modular Competence-Based Curriculum and Technologies for Its Implementation into Higher Vocational Institutions. Asian Social Science, 11(2), 246-251.

Shaidullina, A. R., Krylov, D. A., Sadovaya, V. V., Yunusova, G. R., Glebov, S. O., Masalimova, A. R., \& Korshunova, I. V. (2015). Model of Vocational School, High School and Manufacture Integration in the Regional System of Professional Education. Review of European Studies, 7(1), 63-67.

Sheremet, A. N. (2009). Formation of academic mobility of the future teachers of computer science by means of information and communication technologies (p. 208) (Author's abstract of dissertations of candidate of pedagogical sciences). Novokuznetsk: Kuzbass State Pedagogical Academy.

Sylvia, G. M. (2000). Academic pilgrims XIX CESE Conference (Abstracts of Presentation). Bologna.

Shevchenko, E. V. (2000). The collection of documents relating to the international aspects of higher education (p. 324). St. Petersburg.

Tregubova, T. M., Sakhieva, R. G., \& Masalimova, A. R. (2008). Academic mobility of students in higher education: national and international experience of its formation (p. 131). Kazan: Otechestvo.

Znovenko, L. V. (2008). Development of academic mobility of students of pedagogical college in the conditions of continuing education (p. 23) (Author's abstract of dissertations of candidate of pedagogical sciences). Omsk: Omsk State Pedagogical University.

\section{Copyrights}

Copyright for this article is retained by the author(s), with first publication rights granted to the journal.

This is an open-access article distributed under the terms and conditions of the Creative Commons Attribution license (http://creativecommons.org/licenses/by/3.0/). 